\title{
Report of the Annual Meeting
}

Rapports annuels de la Société historique du Canada

\section{Clearing the Decks for the Loyalists}

\section{Margaret Ells}

Volume 12, numéro 1, 1933

URI : https://id.erudit.org/iderudit/300117ar

DOI : https://doi.org/10.7202/300117ar

Aller au sommaire du numéro

Éditeur(s)

The Canadian Historical Association/La Société historique du Canada

ISSN

0317-0594 (imprimé)

1712-9095 (numérique)

Découvrir la revue

Citer cet article

Ells, M. (1933). Clearing the Decks for the Loyalists. Report of the Annual Meeting / Rapports annuels de la Société historique du Canada, 12(1), 43-58. https://doi.org/10.7202/300117ar d'utilisation que vous pouvez consulter en ligne. 


\section{CLEARING THE DECKS FOR THE LOYALISTS}

\section{By Margaret Ells}

One of the most important problems presented to the British North American provinces by the coming of the Loyalists was that of providing the new settlers with land. In Ontario, it was a question of surveying and alloting sufficient quantities of Crown land to accommodate a large number of immigrants. In Nova Scotia, the problem was complicated by the fact that, during the thirty-four years previous to the Loyalist migration, the provincial government had granted away some five and a half million acres of land*. Before aclequate provision, both as to quantity and quality of land, could be made for the thirty-two or three thousand Loyalists and disbanded troops, such of these grants as had not been improved must be revested in the Crown. This could be effected only by legal process in the provincial Court of Escheats and Forfeitures. The purpose of this study is to discover to how great an extent land speculation and government policy, during the period between the founding of Halifax and the end of the American Revolutionary War, made the escheating of land necessary in clearing the decks for the Loyalists.

The founding of Halifax was the first of a series of imperial projects in carrying out a new policy of settlement in Nova Scotia. It was followed by a few hundred settlers, chiefly from the New England colonies. Due to various reasons, some of which were removed by the expulsion of the Acadians, the policy brought comparatively few permanent inhabitants during the first decade, but, when Governor Lawrence expelled the Acadians, he removed the fears, entertained in New England, of Nova Scotia becoming a French centre of intrigue and possible base in time of war, and at the same time vacated the most fertile lands in the province. The result was that the value of Nova Scotia as an area of expansion for the northern American colonies was appreciably enhanced. Since it was from these districts that the Home Government hoped that the new inhabitants would come, the results of the expulsion in this regard were highly satisfactory to English officials, who were ready to listen to further plans for encouraging immigration to Nova Scotia.

By the summer of 1759 Lawrence had worked out a complete plan for settling the province with people from New England. Previous to receiving it, however, the Board of Trade had had intelligence of his proposals to provide food and transportation, in addition to lands, to the immigrants. Alarmed at the prospect of a heavy bill of expense, their Lordships hastened to urge that, if any settlers were to receive such aid, it must be His Majesty's loyal troops, whom they insisted on picturing as ideal colonists. ${ }^{1}$ Lawrence, having already despatched his plan ${ }^{2}$ for the settling in Nova Scotia of more than twelve thousand New Englanders, whose qualities as pioneers had hitherto been praised by the Board,

\footnotetext{
* See Canadian Archives Report 1894, p. 104 Memo. dated 23 April, 1783.

1 See P.A.N.S. Vol. 30 doc. 29, Lords of Trade to Lawrence, 1 August, 1759.

See P.A.N.S. Vol. 220 doc. 46, Lawrence to Lords of Trade, 20 September, 1750.
} 
answered their Lordships by quoting their previous instructions, favouring these people, and by reiterating forcibly his perfectly reasonable objections to trying to settle the province with disbanded troops. ${ }^{3}$ The Board were completely won over by the force of the Governor's argument, Lawrence was instructed to proceed with his plan, and the problem of disposing of disbanded troops was relegated to the background. ${ }^{4}$

In order that possible settlers might become acquainted with the new land policy, and the advantages it offered in Nova Scotia, the Governor had already issued two proclamations. The first was made public on the twelfth of October, ${ }^{5}$ and stated that, since England had defeated France and thereby removed the ancient fear of attack,an oppartunity for settling the province now offered, and that the Governor accordingly invited proposals for effectual settlement; the proclamation concluded by describing the vacant land in glowing terms. It was followed, three months later, by another which was designed to answer questions raised by New Englanders interested in the project of settling Nova Scotia. The proclamation of January the eleventh, 1759, laid down the conditions under which lands were granted in the province for the ensuing five years. It set a limit of one thousand acres per person, and offered proportions of one hundred acres to each head and fifty to every other member of a family, to be granted on condition that one-third of the land be improved within ten years, two-thirds within twenty, and the entire grant by the end of thirty years, and that the grantee pay a yearly quit rent of one shilling for every fifty acres. No fees were charged for granting land, and payment of the quit rent was remitted for ten years. If the rent remained unpaid for three years, or if the land were not improved, grants made under these conditions became forfeit. ${ }^{6}$

The first escheating grew out of this policy of encouraging settlers. In 1759 an Act was passed for "the quieting of possessions to the Protestant Grantees of the Lands formerly occupied by the French Inhabitants", which provided that no action should be retained in any court in the province for the recovery of lands "by virtue of any right, title, claim, interest or possession of any of the former French inhabitants". It had the effect of a general escheat of all lands vacated by the Acadians and cleared the way for new inhabitants. The Act, moreover, by guaranteeing a clear title to any land granted or to be granted, gave promise of security and thus encouragement to prospective settlers.

This Act and the first regular escheat after the Expulsion had a common object: to prepare for new settlers. The Act was general and related to Franch lands; the first escheat was specific and dealt with two British grants. Prompted by applications in the autumn of 1759 from land agents for two townships, one on Chignecto Basin, the other on Pisiquid River, an enquiry was begun on two grants of fifty thousand acres each, made to Governor Philipps and others in $1736 .{ }^{8}$ The procedure of escheat,

\footnotetext{
${ }^{3}$ See P.A.N.S. Vol. 36 doc. 43, Lawrence to Lords of Trade, 10 December, 1759.

- See P.A.N.S. Vol 30 doc. 34, Lords of Trade to Lawrence, 7 March, 1760.

5 See P.A.N.S. Vol. 211, pp. 27, 28, Minutes of the Executive Council of 12 October, 1758 for first proclamation; and p. 35 , Minutes of 11 January, 1759 for second proclamation.

- See P.A.N.S. Vol. 348, Royal Instructions to Lawrence, Article 63.

7 See MSS. Acts of N.S. Legislature for 1759,33 Geo. il, cap. 3.

8 See P.A.N.S. Vol. 211, p. 90, Councll Minutes, 26 October, 1759.
} 
laid down by Article 51 of the general Instructions, ${ }^{9}$ and confirmed for Halifax County by the provincial Act 31 Geo.ii cap. 8 , was as follows: the Council, having found that the grantees had not fulfilled the conditions of the grant, advised the Attorney-General "to prosecute a suit against the Grantees for the legal recovery of the Same," a Commissioner was appointed and a jury of twelve called. This court found the conditions unfulfilled, ${ }^{10}$ the proceedings were returned to Chancery, and on the twenty-first of April the grants were declared to be escheated. The government was thus enabled, as the Council had anticipated, "to grant the said lands" to the agents, who "were desirous immediately to cultivate and improve them."

The policy of encouraging settlers, begun by Lawrence in 1758 and incorporated in the two proclamations, the general escheating Act and the first trial of escheat hitherto discussed, began to bear fruit in the Spring of 1760 . The considerable stream of migration from New England which followed, warranted a continuation of the policy after the death of the Governor who sponsored it. Lawrence died suddenly in October 1760, and was succeeded in March by Henry Ellis, who remained in England, and left Nova Scotia to the ministrations of Jonathan Belcher, Lieut-Governor. For three years Belcher carried on Lawrence's plans of settlement. In 1763 he was succeeded by Montagu Wilmot, and, when the Instructions for the new. Governor came, it was evident that a change had taken place in imperial circles, as regards the granting of land.

C. W. Alvord ${ }^{11}$ has shown the forces that were at work in ministerial circles during the days after the signing of the treaty, when questions of American policy were being threshed out. By his evidence it appears that. by the Spring of 1763, the Lords of Trade had already decided to prevent the westward expansion of the American colonies by making an Indian reservation of the newly acquired lands west of the Alleghanies, and by offering inducements which they hoped would attract settlers away from the boundary into the older colonies. While they were formulating the conditions upon which land would be offered, ${ }^{2}$ the outbreak of the War of Pontiac's Conspiracy made immediate action imperative. Rather than use the regular and slow means of transmission of orders by instruction to the Governor, they "determined on a proclamation to inform the Indians of the good intentions of Government." 13 The proclamation would also acquaint the colonials with the inducements to be offered settlers in various places including "the old colony of Nava Scotia to which the ministry was particularly favourable." 13 It was thus with the primary aim of using Nova Scotia as a counter-attraction to the Mississippi Valley as a sphere of settlement, that the Home Government embarked on its new land policy expressed in the Proclamation of 1763 and the Royal Instructions of the following year.

- Ibid. Vol. 348 doc. 11, Royal Instructions to Lawrence, 1756.

10 See Vol. 36 doc. 47, Lawrence to Lords of Trdae, 11 May, 1760.

${ }^{11}$ See "The Missippi Valley in British Politics," A. H. Clark Co., Cleveland, 1917, vol. I pp. $188 \mathrm{ff}$.

${ }_{12}$ For example McNutt's special instructions, some of which were incorporated in the general instructions, were complete by May, 1763 .

13 See Alvord op. cit. p. 188. 
The Proclamation of the seventh of October, $1763,{ }^{14}$ and the Instructions which were composed to accord with it, and which followed Wilmot to Nova Scotia in the Spring of 1764 , considered along with a letter from the Lords of Trade as to executing them reveal important changes in imperial policy. The letter evinces the Home Government's determination to test all administrative machinery:

"The re-establishment of public Peace upon Terms of so great Glory to His Majesty's Kingdom, makes it the duty of every department of office entrusted, in the least degree, with the administration of public Affairs, to give their utmost care \& attention to the extending and improving the advantages to be derived from the late definitive Treaty. By this Treaty every obstruction to the further Settlement of the American Colonies has been removed, ......'15

As suggested by the last sentence, the machinery involved in the granting lands was not left out of the general house-cleaning. Previous Instructions and reports, indicating their effect on settlement and the degree to which they were enforced, were weighed in the balance by the Board and found wanting. It was then determined to draft new Instructions, which should remedy the defects of the old ones, cover the new conditions created by the peace treaty and provide ample encouragement to settlers. These Instructions, slightly modified, continued to guide the Governors of Nova Scotia in granting land, for ordinary purposes, until the end of the century. The terms they imposed, and how and why they differed from those previously in force, must therefore be discussed here.

The Board of Trade described the new Instructions to Wilmot in these words :

"His Majesty's Instructions, which you will receive by this conveyance, will mark out to you with the greatest exactness the plan which you are to follow, for the future, in making Settlements within the Province under your Government; and, though the several regulations in respect to the division of the Country, and the conditions to be complyed with by Grantees, do, in many respects, differ from those prescribed in the Instructions to your Precedessors, yet no difficulty can, we conceive, arise in the execution of them, since they do in general follow the plan of Division which had been observed by $\mathrm{Mr}$. Lawrence, with very little variation, and in respect to the conditions are more explicit and less equivocal than the former Instructions." $1 \mathrm{o}$

In illustration, the Board might have pointed to Article 53 of the Instructions, which required that for every fifty acres of land which the grantee desired to retain, he must, in three years, improve three acres by clearing, building, digging, or placing cattle, according to whether the land were fertile or barren, that quit rents became payable within two years of the date of grant and land liable to forfeit after one year of non-payment, and that, in addition to the ordinary allowance, lands amounting to as much as one thousand acres to a family, might be granted on payment of purchase money at the rate of five shillings per fifty acres; or they might have referred to Article 55, which directed the Governor to publish the Instructions as the only terms on which lands would be granted. ${ }^{17}$ Contrasted with the conditions emanating from the same source and laid down by Lawrence in his second proclamation, these Instructions were indeed "more explicit and less equivocal."

\footnotetext{
14 See Short and Doughty: Const. Documents 1759-1791, Vol. 1, p. 163.

15 See vol. 31, doc. 29, Lords of Trade to Wilmot, 20 March, 1764.

10 See vol. 31, doc. 29, Lords of Trade to Wilmot, 20 March, 1764.

17 See Vol. 349, doc. 9, Royal Instructions to Wilmot, Art. 44-62 for regulations as to granting land.
} 
Although they stressed the points, incorporated in Articles 53 and 55 of the Instructions, wherein they had provided more elaborate regulations, the Board passed by in silence those alterations made to jibe with movements behind the scenes at Whitehall. Formulated, as has been shown, to implement a policy of attracting settlement away from the Mississippi Valley, at a time when English and Colonial interest in speculation had reached the proportions of a land rush, ${ }^{18}$ the Instructions gave evidence of the land jobbers' influence. Thus they did not require the alienation clause, which had hitherto prevented grantees from selling their land, except by special license from the Governor. Moreover, while providing detailed directions for making small grants, the Board nullified their good effect and paved the way for speculation on a large scale by including among the Instructions Article 52, which allowed the Governor to grant tracts, without limit, to any persons who proposed to settle them. The size of the grant, the number of settlers to be introduced, and the sincerity of the promoter were all left to the judgment of the Governor.

When they transmitted the new Instructions, the Lords of Trade had added a final warning and request:

"We expect therefore that you will be particularly careful that the several directions, with respect to these points, contained in your Instructions, are most faithfully and exactly obeyed; and if there are any other Checks or regulations that shall occur to you, by which His Majesty's Instructions, in these particulars, may be more effectually answered, you will endeavour to establish them as far as your own authority extends, representing to us what may be further necessary to be done here, or what further powers it may be proper to give you." 19

On receiving this letter and the Instructions, Wilmot took prompt advantage of the opportunity offered, and, in a long despatch, passed under review the several alterations. ${ }^{20}$ He saw the dangers of omitting the alienation clause, and recommended that it be reinstated. He doubted the advisability of decreasing by eight years the period between the date of grant and that when the quit rent became due, and of giving the grantee only one year instead of three before non-payment of the rent rendered the grant liable to escheat, on the ground that they tended to discourage poor but often valuable settlers; and he objected to publishing the Instructions, in the other colonies and in Nova Scotia, as the only terms ${ }^{21}$ on which grants could be made. ${ }^{2}$

After stating his doubts and objections, Wilmot announced his determination to wait for further orders before publishing and enforcing the regulations. ${ }^{2} 3$

The Lords of Trade did not alter their policy as incorporated in the new land Instructions; they did not even answer the Governor's despatch. The result was that one of his prophecies was speedily fulfilled. In objecting to the omission of the alienation clause, Wilmot expressed his apprehension lest "it might be an invitation for several people to come here

18 See Alvord: op. cit. p. 213 , note 381.

Io See Vol. 31, doc. 29, Lords of Trade to Wilunot, 20 March, 1764.

${ }^{20}$ See Vol. 39, doc. 9, Wilmot to Lords of Trade, 24 June, 1764.

21 An addition requiring that the Governor publish his land-granting Instructions had also been made to the clause relative to grants in Wilmot's Commission. See his Commission in P.A.N.S.; and see Short and Doughty op. cit. p. 171 for a similar clause in Gov. Murray's Commission.

${ }_{22}$ He also objected to the payment of purchase money, being under the impression that it had to be paid, not only on the additional thousand acres, but on all grants.

${ }^{23}$ In this he was fully supported by the Executive Council: see Vol. 211, p. 354, Council Minutes for 4 June, 1764. 
and take up Lands, with a view of selling them in a short space of time; whence falling, perhaps, into the hands of improper persons, and frequently changing proprietors, the progress of improvement might greatly suffer." 24 Speaking at a time when certain agents and large numbers of private owners were asking for grants, the Governor had good reason for urging his views, which were fully justified in the events of 1765. A great wave of land speculation engulfed the province, and grants were made in such numbers and of such dimensions as to provide the Courts of Escheats with business at intervals for half a century, for the last escheat of lands granted in that fruitful year was not made until $1816 .^{25}$ Seven times more subsequently escheated acres were granted during 1765 than in the other thirtythree years of the pre-Loyalist period. It was largely these grants which necessitated the heavy escheating that heralded the Loyalists' arrival. How they came to be made therefore becomes a question pertinent to this study.

The new Instructions arrived in June 1764. While awaiting a reply to their representations respecting them, the Governor and Council proceeded to grant lands according to the old regulations. Demands for grants continued to pour in, but the old limits were not exceeded, except in one instance. ${ }^{20}$ By December no word had come from Whitehall to countermand the Instructions, and the Council, possibly because the constant demand for land led them to expect heavy granting when orders should arrive, established fees to be taken by the Governor. ${ }^{27}$

While the authorities in Nova Scotia were still awaiting an answer from England, and continuing to make small grants on the old conditions, Spring came and with it several land agents. Among them was Colonel Alexander McNutt, who had appeared on the provincial horizon at intervals since 1759, when he had obtained several extensive reserves of land. After an interval which he seems to have spent mainly in memorialising the Board of Trade, ${ }^{28} \mathrm{McNutt}$ now came from Pennsylvania, where he had been recruiting colonists. Full of new and better schemes for settling the province, and a vastly increased sense of his own importance, he could now spread before the Governor the special land Instructions which were the results of his representations to the Home authorities.

These Instructions ${ }^{29}$ applied only to settlers brought in by McNutt previous to 1763, and directed that the land agent was to be given one hundred acres himself for every five hundred granted to settlers whom he brought in; the terms as to quit rent and proportion of lands followed Lawrence's instructions, while as to improvement they were those incorporated in Wilmot's instructions of $1764 .^{30}$ In obedience to these orders the

${ }^{24}$ See Vol. 39, doc. 9, Wilmot to Lords of Trade, 24 June, I764.

${ }_{25}$ See P.A.N.S. Record Book of Escheot, Case No. 209, 13 January, 1816.

${ }^{20}$ Which was under special conditions of settlement, see Vol. 211, p. 402, Councll Minutes for 24 December, 1764.

27 Idern.

28 According to his own evidence, see Vol. 31, doc. 53, he sent in one petition in 1761, two in 1762 and three in 1763 , besides those addressed to the Board after his first return from Nova Scotia.

29 See Vol. 349, doc. 7, Additional Instruction to Ellis; Vol. 31, doc. 53, McNutt's memorial of 17 April, 1766 shows that he had a copy of this, and doc. 55 that it had been delivered to Wilmot in March.

${ }^{30}$ These were conditions suggested in McNutt's memorial of 1761, see Vol. 321, doc. 5, and were part of the Instructions to the Governors of Canada and Nova Scotia. 
Council directed grants amounting in all to 13,500 acres to be laid out for $\mathrm{McNutt}^{3}{ }^{1}$

It was not with the people whom he had already settled, however, that McNutt was chiefly concerned in 1765 , but with the terms for those he was then proposing to bring in. He presented Wilmot with a draft grant in which were included the privileges without which the people who had contracted with him to settle in Nova Scotia would not come. The Governor was impressed; he wrote to the Lords of Trade:

"his applications are of a very considerable degree and extent and he produces many letters from the associations I have before mentioned soliciting him in the most pressing manner to use his utmost endeavours to procure for them the tracts of land for which they apply" on such conditions "as he says were approved of at Your Lordships' board, but as they differ considerably from such as I am authorized from the King's Instructions to Grant, I must wait until I shall have your Lordships' directions for my conduct in this Matter." He therefore enclosed McNutt's proposals, leaving it "for the determination of your Lordships whether the sudden acquisition of a very considerable number of the most beneficial settlers some of whom are at this present time so zealous in this undertaking as to be making preparations, will not produce more advantages to the public than any which can be derived from the difference of terms and conditions." 82

Wilmot also announced his intention of making reservations, while waiting for their Lordships' reply, on the condition, proposed by himself, that one-quarter of the number of immigrants to be settled should be brought in within a year of the date of reservation, and the settlement completed within four years. Accordingly, between June seventh and July second, the Council made reservations aggregating 2,300,000 acres to McNutt and his associates. ${ }^{3} \mathbf{3}$

During the summer surveying went on apace, and applications for land, based on the promises of the Proclamation of 1763 and on the authority of special Orders-in-Council, poured in. The Governor was still making small grants on the old conditions safeguarded by the alienation clause, and reserving large tracts, but delaying to take the plunge of granting largely until the last minute. It was clear that the general Instructions of 1764 were no more acceptable to those who wanted land, than to those who granted it, for the conditions they imposed neither encouraged the land agents who really intended to bring settlers in, nor discouraged those who were mere speculators. Yet by October the Home Government had not shown sufficient interest in the agents' proposals to send special orders regarding them, and the restlessness of the agents required that some decision soon be made. Another element had entered into the situation with the news of the passing of the Stamp Act. Unless their grants were made before the first of November, when the Act would come into force, the agents would be obliged to pay an extra ninepence a quire for the paper on which their grants were made out, and a tax of threepence for each grant. Any tendency of the Council to delay beyond that date was checked by the agents' threat of giving up their projects rather than pay the taxes, and the question seemed to resolve itself into choosing between absolute loss of settlers and a wholesale breach of Instructions.

\$1 When, in 1766 , McNutt complained that this special Instruction had not been carried out. Michael Franklin, then Lieut-Governor, pointed out that they had granted this amount (by mistake he aggregated the acres at 15,000) to reward McNutt for his earlier efforts, but as they had never been able to procure from him lists of his settlers, the exact number could not be ascertained; 150 families, with an average of 500 acres to a family, were therefore taken as the outside number; see Vol. 37, doc. 51, Franklin to Lords of Trade, 2 September. 1766.

see Vol. 37, doc. 42, Wilmot to Lords of Trade, 20 April, 1765.

an See Vol. 211, pp. 418-423, Council Minutes, 3 June to 2 July, 1765. 
In the dilemma which developed as the first of November approached, Wilmot had two alternatives. He could play safe by refusing to make large grants except on the old conditions, (which would be rejected, he knew) until he had specific instructions from England, thereby losing all the settlers and official fees, ${ }^{34}$ or he could disregard the Instructions entirely, give the grants on the conditions asked for, and trust that the success of the land agents' efforts would justify the breach of Instructions. In following either course Wilmot risked serious reproof: if he obeyed his orders and the agents and immigrants were turned away, he was liable to be charged with defeating imperial and provincial interests in settling Nova Scotia; if he let them in on their own terms, he might be recalled for ignoring his Instructions, especially if the agents did not fulfill their obligations and he could not point to the settling of the province as an excuse for his disobedience. Between these two courses of action Wilmot compromised. $\mathrm{He}$ and the Council decided that the settlement of the province was more important in the eyes of Government than adherence to unreasonable Instructions. They therefore determined to give the agents an opportunity to achieve it, by granting them the land they demanded. But, being skeptical of the land jobbers' ability, Wilmot attached a condition to the grants calculated to protect the province against the evil effects which would accrue if they failed. This provision, suggested by the Governor in April as attaching to the reservations then made, was that one-quarter of the total settlers for each township granted should be brought in within a year of the date of the grant, one half within two years, and the number completed within four years or the land forfeited. The agents were thus given the means of proving their sincerity, while, if they were dishonest, the damage was minimised by the land being bound for only four years. As Franklin wrote when he was defending this action: "it would be an essay of the Abilities and disposition of these people on the least risk and prejudice to the Crown ...... and the whole would be determinable in four years; probably with some considerable advantages to the public but without any possidle loss." 35

Thus it came about that the last seventeen days before the coming into force of the Stamp Act witnessed the granting away of three million acres of land in Nova Scotia. McNutt and his associates alone received one and a half millions. In this fashion Nova Scotia took part in the wave of land speculation which, between 1764 and the American Revolution, swept the continent. For, with the exception of negotiations involving less than 300,000 acres, land speculation in the province was limited to the year 1765. The interests of the Home Government in preventing colonial expansion to the west, its negligence of Nova Ssotian interests when they clashed with those of persons of influence, and the persistence of McNutt and other land pirates combined to place the provincial authorities in an unfortunate position, which was intensified by the prospect of material gain from the fees involved. The imminent enforcement of the Stamp Act made escape impossible and a decision imperative. That Act, which

\footnotetext{
as These had been established for the Sec'y and Chief Surveyor in 1760 , see Vol. 211, p. 145. and for the Governor in 1764 , (p. 402) and amounted to $x 2$ on a 500 -acre grant, 22.15 .0 . for 1000 acres, and increased proportionally with the quantity and the number of grantees of the larger grants.
}

as See Vol, 37, doc. 51, Franklin to Lords of Trade, 2 September, 1766. 
has been generally regarded as having caused hardly a ripple on the surface of provincial life, was thus indirectly responsible for the only land rush Nova Scotia has ever known.

By the speculation of 1765 vast areas of wilderness land in the south, east and northeast of the peninsula, and most of the lands surrounding the St. John, Peticodiac and Memramcook Rivers were given away. The terms upon which Wilmot and the Council had finally made the grants, while they differed in minor cletails with the circumstances, ${ }^{\mathbf{3}}{ }^{6}$ followed fairly closely Lawrence's Instructions of 1756 . Needless to say, the end of the four years of grace found practically all the grants unimproved. The nebulous schemes of McNutt were definitely frustrated when the Home Government decided to prevent the depopulation of Ireland by vetoing Irish emigration, which had formed the basis of the plans of McNutt and other agents. ${ }^{37}$ For various reasons the promoters were prevented from completing the St. John River settlements. ${ }^{\text {s }}$ By 1770 , therefore, most of the grants of 1765 had become liable to escheat through non-fulfilment of conditions. There were two conditions necessary to an escheat: a grant of land which had become forfeit, and a demand for that land. As a result of the speculation of 1765 , and of the precautionery measures which Wilmot was wise enough to take in making the grants, forfeited though unescheated land was a constant factor after 1770 in Nova Scotia. Whenever there should be any demand for the land escheats would inevitably take place.

Although the orgy of granting in which the Nova Scotia authorities indulged during October 1765 marked the high tide of the land rush, it did not altogether exhaust the demand for provincial land. Further granting was somewhat restrained, however, by the increased expense caused by the Stamp Act, ${ }^{\mathbf{9}}$ and by the uncertainty of the officials as to the reception their action in making the grants of 1765 would meet in England. The Government's attitude in this regard was at first determined by McNutt's distorted view, as presented in his memorial of April seventeenth, 1766, ${ }^{\mathbf{4}}$ and therefore unfavourable. Their letter, ${ }^{41}$ enclosing the memorial, reproving Wilmot for breaking his Instructions, and clemanding an explanation, reached Nova Scotia after Wilmot's death, and Green, who was administering the government, left the task of explaining to the newly appointed Lieut-Governor, Michael Francklin, who performed it successfully in his despatch of September second. ${ }^{42}$ Although the Board accepted Francklin's explanation, (they seem not to have replied to this letter) they did not alter their policy; and when Campbell became Governor in December, his Instructions showed no change, and the regulations sent to Wilmot two and a half years earlier were first enforced.

so The number of settlers per township differed in the various grants on the St. John River, see Raymond: Townships on the River St.John, N.B. Hist. Society Publications, Vol. VI, pp. 30s, 30t, also with those granted McNutt, see his memorial (Vol. 31, doc. 53).

97 See Vol. 31, doc. 54, Lords of Trade to Wilmot (enclosure) : Alvord, op. cit. Vol. 2, p. 120, suggests that this was Hillsborough's action, because he had large estates in Ireland.

38 See Raymond, River St. John, p. 379 ff. for reasons,

so Vol. 221, doc. 20, a grant to Wm. Spry, dated 5 November, 17tis, shows that the Council were still using lawrence's Instructions for grants after the Stamp Act came into force.

40 See Vol. 31, doc. 53, Enclosed in Lords of Trade to Wilmot, 16 May, 1766.

¿I Idem. doc. 55, Lords of Trade to Wilmot, i6 May, 1760.

42 See Vol, 3\%, doc. 51, Franklin to Lords of Trade, 2 September, 1766. 
On the terms of these Instructions applications continued to give evidence of the interest of individuals in owning Nova Scotian land until the new Instructions of 1773 were formulated. As the four years of trial upon which the 1765 grants had been made drew to a close, petitions for these undeveloped lands occasioned the first escheats recorded in the Case Book of the Court of Escheats. Case number one was brought before the Commissioner and tried in May of 1770 , and proved to be McNutt's township grant on Pictou Harbour. The second and only other case tried in this year was also a McNutt grant; the two escheats totalled 250,000 acres. The prospect of further escheating caused the Council to regularise procedure. This was done in September by establishing fees for all officers in the Court of Escheats. ${ }^{43}$ But the quarter of a million acres already re-vested in the Crown seems to have been sufficient to supply the demand for a year, at the end of which, orders from England called a halt. When Campbell reported on the escheating of 1770, he asked the Secretary of State for more adequate instructions as to regranting the lands $;^{\mathbf{4}}$ in reply, Hillsborough directed him to regrant no land without explicit directions from England, and to transmit to the Home Government all proposals for settlement, that appropriate instructions might be given." By this order the process of granting was lengthened by the necessity of referring to England, and the demand for lands, forfeited or ungranted, was restrained. By 1773, however, sufficient petitions had accumulated to impel the escheating of 116,436 acres. ${ }^{46}$

The indication of a change, tending toward restraint in land granting. which had been conveyed by Hillsborough's order of 1770 , was confirmed three years later. On April seventh, 1773, the King issued a proclamation directing the Lords Commissioners for Trade and Plantations to take into their consideration the powers for granting land contained in the Commissions and Instructions to the colonial Governors, and ordering that:

"in the meantime and until His Majesty's further pleasure be signified all Governors ... . do forbear in pain of His Majesty's highest displeasure, and of being immediately removed from their office, to issue any warrant of survey or to pass any patents for lands in the said colonies ..... without especial direction from His Majesty for that purpose" under the sign manual or by order-in-council, except to officers and soldiers by virtue of the Proclamation of October seventh, 1763.47

Governor Legge, who succeeded Campbell in October, was placed under the same prohibition, ${ }^{48}$ and in 1774 the outcome of their Lordships' deliberations was an additional Instruction, ${ }^{49}$ which continued the prohibition on granting and gave directions for offering provincial land for sale.

The selling of forfeited land, first put forward by Shelburne, ${ }^{50}$ had been suggested to Campbell by the Secretary of State, to meet the expense of escheating ; ${ }^{51}$ Campbell objected ${ }^{52}$ that it would bring in only a trifle and discourage settling, to which Hillsborough replied that:

1. See Vol. 212, pp. 141-2, Council Minutes, 19 September, 1770.

4 See Vol. 48, doc. 108, Campbell to Hilsborough, 9 October, 1770.

45 See Can. Archives Report 1894, p. 302, Hillsborough to Campbell, 11 Dec.

'See Case Book, Cases 3-11, 5 May to 23 August, 1773.

17 See Vol. 212, p. 180, Council Minutes, 20 July, 1773.

48 See Vol. 349 , doc. 24, Royal Inst. to Legge, Art. 45.

40 Idem. doc. 26, Additional Instruction to Legge, 3 February, 1774.

so See Alvord op. cit. Vol. II, p. $212 \mathrm{ff}$. for development and general application of the plan.

61 See Arch. Rpt. 1894, p. 305, Hillsborough to Campbell, 3 July, 1771; In April Campbell had represented that the last escheats had not been paid for, see P.A.N.S. Vol. 43, doc. I13.

62 See Arch. Rpt. 1894, p. 306, Campbell to Hillsborough, 16 September, 1771. 
"If it be really the case that the land is of such little value that the fee simple would not sell for so much as would pay the expense of a prosecution in the Court of Escheats, it certainly cannot be worth the Crown's while to pay that expence merely for the sake of the Quit Rent which is all the advantage (and that a very precarious one) the Crown would get by the Forfeiture." 53

The whole matter was taken into consideration by the Privy Council and instructions for preparing land for sale were formulated and despatched to all colonial Governors. Although there had been many people willing to make the experiment of pioneering on land given gratis, there was none, as Campbell had prophesied, who would pay for the privilege. The result was a cessation of demands for land, and a consequent lull in escheating, which lasted seven years.

The new Instructions limiting the disposal of land in Nova Scotia to terms of sale had been in force only a year, when events in the other colonies led to their modification eventually increased the demand for land, and consequently affected the rate of escheat. Following the outbreaks in the New England colonies of 1774, the Secretary of State detailed the changes which were made necessary by the violence of the rebels as follows:

"It is therefore the King's pleasure that the execution of the plan for the disposal of lands by sale, directed in His Majesty's Instructions to you of the 3rd February 1774 be for the present suspended, and that you do make gratuitous grants to all persons who may be driven to seek shelter in Nova Scotia, from the tyranny and oppression that prevails in those colonies, where rebellion has set up its standard; the said grants to be exempt from quit rents for ten years, and to be made in such quantities and situations as shall correspond with the condition of the persons applying for the same." 54

It is worth noticing that the directions as to terms on which the Governor was to grant lands to refugees were vague in the extreme, and left a great deal to his judgment. Despite the attractions offered them, refugees who asked for land in Nova Scotia were so few that they could easily be accommodated on the lands previously escheated. Prior to the coming of the Loyalists, therefore, little escheating was needed to supply the needs of refugees. ${ }^{65}$

Except as regards Loyalist refugees, Legge's Instructions of 1773 and 1774 remained in force until Parr became Governor in 1782 . Since they forbade the granting of land, the natural inference is that no escheats, other than the few needed to provide land for the small number of refugees, would be made for the ten years following their enforcement. UP to 1780 this was true. But the Case Book shows that no less than fifteen actions for escheat were adjudicated in 1780 and 1781 , and that 210,350 acres were thereby re-vested in the Crown. ${ }^{56}$ The explanation of this anomaly lies in the Minutes of the Executive Council for the two years. These show a reviving interest in aquiring land, in which the provincial officials joined, and which they satisfied by making reservations of the lands they wanted until the King's pleasure should be known. Hence the following entry:

\footnotetext{
${ }^{63}$ See Vol, 32, doc. 10, Hollsborough to Campbell, 27 March, 1772.

64 Ibid. doc. 31, Darmouth to Legge, 1 July, 1775.

ss Several of the 1781 escheats were quite possibly for these people, but there was none previously.

to See Case Book, Cases 12-26, 19 April, 1780-8, August, 1781.
} 
"Resolved that the townships formerly granted Alexander MeNutt Esq. and associates at the Shedeboak and on the River Philip be reserved until the King's pleasure be known, at the request of Sir Richard Hughes, Chief Justice Finucane and Mr. Butler (member of Council) each of whom are to apply for 20,000 acres of said townships." 57

The Council doubtless expected some modification of the restriction on grants to follow the war, which was obviously drawing to a close, and wished to be well in the foreground with their demands. In the light of these reservations, the escheating of 1781 becomes explicable. Of the land thus redeemed to Government little had been regranted before $1783 ;{ }^{5} \mathbf{8}$ the $1781^{59}$ escheats had therefore a very real, though unintentional, part in clearing the decks for the Loyalists.

Although the escheating of 1770,1773 and 1781 resulted inadvertently in making room for the Loyalists, that was not their raison d'être. The first action for escheat impelled by preparations for providing Loyalists with land was not begun until the Spring of 1783, when three hundred of the new settlers had been in the province half a year, ${ }^{60}$ and 8000 more were preparing to embark at New York for Nova Scotia. This lateness was due primarily to the fact that the new Governor only arrived in October of 1782 , and the multiplicity of business, incidental to fitting into office and making immediate provision for the refugees who followed hot on his heels, fully occupied his attention for the rest of the year. Since it was uncertain how many refugees, Loyalists and disbanded troops would come to Nova Scotia, the amount of land that would be needed to settle them was highly conjectural. Parr, moreover, had as yet no special directions relating to giving land to these people. Unless large numbers were coming, or they were to be given larger grants than ordinary applicants, there was no pressing need for instituting processess of escheat.

During the winter it became obvious that both these conditions were to be fulfilled. Despatches from Sir Guy Carleton, who was preparing to evacuate New York, indicated that large numbers might be expected, and that they would receive very special treatment from the Home Government. ${ }^{61}$ Actions for escheating land were therefore begun in March. Parr's Instructions reveal that Government had performed a volte face in its policy of granting land. Settlement on government land was now to be energetically encouraged. ${ }^{62}$ The terms on which Parr was permitted to make grants reverted, for the most part, to those which were incorporated in Wilmot's Instructions of 1764 . They, ${ }^{63}$ it will be remembered, allowed one hundred acres to each head and fifty acres to every other member of a family, which worked out to approximately five hundred acres per family. As the summer of 1783 came and went immigrants poured in by the thousands, the necessity of providing land for them at the rate of five hundred acres to a family materialized, and escheating went on apace. But the officials had

${ }^{97}$ See Vol. 212, Council Minutes, p. 477, 17 June, 1781.

58 See List of Grantees in N. S. for 1781 and 1782 in P.A.N.S.

so See Case Book, only one of the I5 actions was tried in 1780 .

600 had arrived at Annapolis in October, see C.0. $217 / 56$, p. 40 .

o1 See P.R.O. C.O. 5/108 Carleton to Parr, 22 December, 1782; also 217/56, p. 40, Parr to Secretary of State, 20 October, 1782, asking for special Instructions which Carleton had indicated would be needed.

62 Ibid, 217/34, p. 221, Unsigned to Lord President, 22 August, 1782-remarks on Parr's Instructions.

o Ibid, 218/9, Royal Inst. to Parr, I782, Articles 45-52 incl. 
to provide land for old as well as new settlers, for, after it became known that Parr's Instructions removed the old restrictions on granting land, petitions for grants poured in from the old inhabitants. The simultaneous publication of the Governor's Instructions concerning land, and of the news, brought by the Loyalist vanguard, that many more settlers were expected in the Spring, resulted in a typical display of New England acuteness and an increased demand for escheating. On the twenty-second of April, before the choice of land had been limited by providing for the seven thousand Loyalists who were embarking in the Spring fleet, applications for land from fifty-four old inhabitants resulted in the granting of 50,750 acres on the Stewiacke and Kennetcook Rivers. ${ }^{64}$ Between March and December 860,260 acres, covering areas chiefly in the west of the peninsula and around the St. John River were escheatd. ${ }^{65}$

The year 1783 marked the high tide of escheating and immigration. During that year the largest number of acres of provincial land was escheated, and some 32,000 settlers came to Nova Scotia. The flow of immigration stopped in the winter of 1784 , but many thousands were still waiting for grants, and the need for escheating continued. That need had been increased by the arrival, in November, 1783, of the anticipated special Instructions relating to the Loyalists. Previous to November, Parr had used the general Instructions, and after that date, they continued to obtain with regard to all grants to persons who were not among the ranks of Loyalists and disbanded troops. The special Instructions, nine in number, ${ }^{6}{ }^{6}$ gave grants of ordinary size to Loyalists, but remitted purchase money, and postponed the payment of quit rent for ten years; they provided for the surveying and making out of grants free; they gave additional grants, varying from one hundired to one thousand acres to troops and officers, under the same remissions. The increased allowance of land given to soldiers, both regular and Loyalist,by these orders precluded the possibility of a lull in escheating. Hence, actions were begun as early as February; by September the last escheat of 1784 was completed. Although after this year actions for the escheating of lands north of the Missiquash River came before the government of the new province of New Brunswick, there were twelve escheats in Nova Scotia in 1785; the next year their number was decreased by one, and there was none in 1787 . With $1788^{\circ 7}$ the burst of escheating occasioned by the influx of the Loyalists came to an end.

Of the hundred and twenty-three actions all but two were successful. ${ }^{68}$ Previous to 1783 more than half a million acres had been escheated, of which Loyalists chiefly reaped the benefit. With the direct purpose of providing for Loyalists 1,488,871 acres were escheated between 1783 and 1788. Thus two and a half million acres of Nova Scotia land 69 had been re-vested in the Crown by legal procedure by the close of 1788 , and on these lands, the Loyalists and disbanded troops who came to Nova Scotia as a result the American Revolution, were settled.

a See Vol, 212 Council Minutes, 22 April, 1783.

w See Case Book, Cases 26-49 incl, and Catalogue of Escheats Court, p. 133.

see P.R.O., C.0. 217/35 Instructions to Parr, 1784 (incorporating the special instructions of the previous year) Art. 53-61 incl.

67 See Case Book, Cases 50-123 for escheats of 1784, 5, 6 and 1788 .

68 Ten of these were not recorded in the Case Book, but are found in the Catalogue of the Court of Escheats and Forfeitures, p. 133 .

60 Including at least 509,000 acres, the grants for which had never been taken out of the Secretary's offce; see Vol, 409, doc. 146, Studholme's report on the St. John River districts of 1783. 
Record of Land escheated in Nova Scotia, 1770-1788.

1770

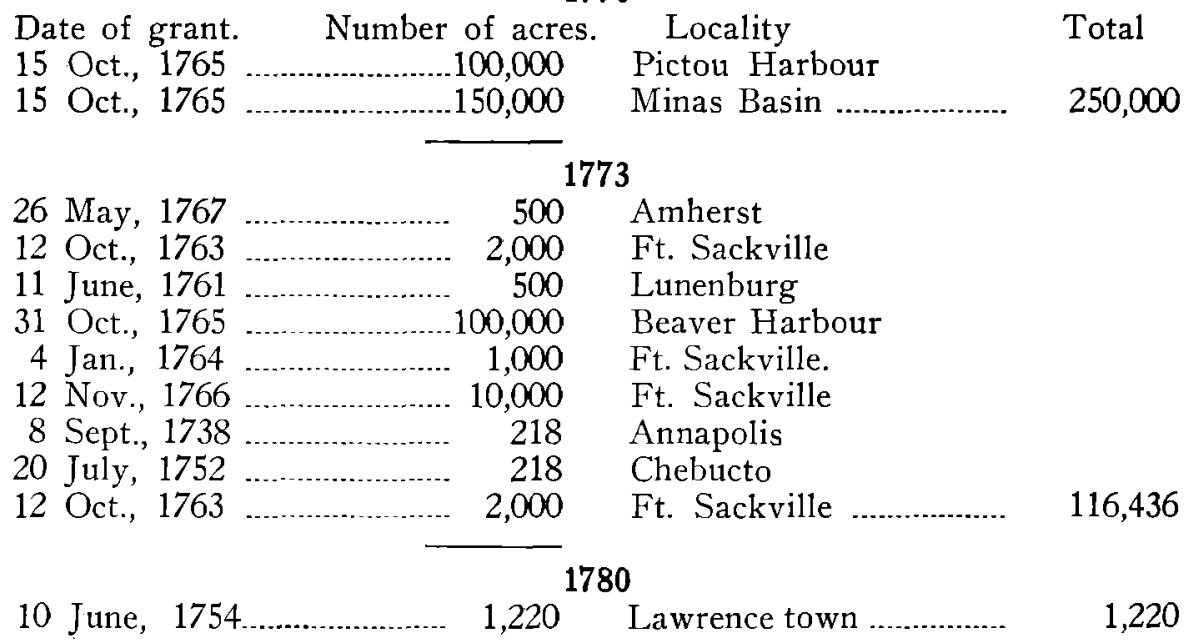

1781

12 Oct., 1763

500

29 June, 1763

4 Feb., 1764

$500 \quad$ Lunenburg

7 May, 1765

1,000

500

12 Oct., 1765

1,000

5 Feb., 1765

500

7 May, 1765

500

19 July, 1764

2,000

4Feb., 1764

1,000

100,000

100,000

31 Oct., 1765

380

$20 \mathrm{July}, 1754$

250

20 July, 1754

1,000

Windsor Rd.

Windsor Rd.

Sackville Rd.

Windsor Rd.

Windsor Rd.

Windsor Rd.

Windsor Rd.

Shedeboack

Bay Verte

Chebucto

Chebucto

31 Oct., 1765

New Dublin

\section{3}

21 Aug., 1767

10,000

2,000

3 Aug., 1769

125,000

200,000

18 Oct., 1765

350

20 July, 1752

100,000

20 July, 1752

10

29 Oct., 1765

100,000

15 Oct., 1765

100,000

20 July, 1752

200

20 July, 1752

200

19 Oct., 1765

100,000

29 Oct., 1765

4,000

Passamaquoddy B.

Crow Harbour

St. Mary's Bay

Liverpool

Chibucto

Port Mouton

Halifax Peninsula

Almeston

C. Negro

Chebucto

Bedford Basin

Gagetown

Annapolis 
Record of Land escheated in Nova Scotia, 1770-1788.-Continued.

\begin{tabular}{|c|c|c|c|}
\hline \multicolumn{4}{|c|}{1783} \\
\hline 19 Oct., 1765 & 50,000 & Conway & \\
\hline 8 Feb., 1770 & 3,000 & Shubenacadie & \\
\hline 30 Nov., 1764 & 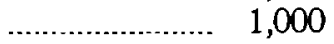 & Shubenacadie & \\
\hline 17 Aug., 1765 & 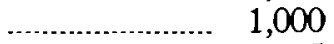 & Shubenacadie & \\
\hline $20 \mathrm{July}, 1752$ & 5 & Halifax & \\
\hline $23 \mathrm{July}, 1767$ & 10,000 & Passamaquoddy & \\
\hline 21 Aug., 1767 & 10,000 & Passamaquoddy & \\
\hline 7 June, 1765 & $\begin{array}{ll}1,500 \\
\ldots\end{array}$ & St. Margaret's B. & \\
\hline 21 Mar., 1768 & $\begin{array}{ll}2,000 \\
\cdots\end{array}$ & Passamaquoddy & \\
\hline 21 Aug., 1765 & 10,000 & Passamaquoddy & \\
\hline 21 Aug., 1767 & 10,000 & Passamaquoddy & \\
\hline 9 Apr., 1761 & 20,000 & Pisiquid .................. & 860,265 \\
\hline \multicolumn{4}{|c|}{1784} \\
\hline 1 July, 1768 & 1,000 & Windsor $\mathrm{Rd}$. & \\
\hline 4 Dec., 1767 & 750 & Barrington & \\
\hline 15 July, 1765 & 2,000 & Petit Passage I. & \\
\hline & 500 & St. Margaret's B. & \\
\hline 20 Mar., 1756 & 800 & St. Margaret's B. & \\
\hline 22 Sept., 1765 & 500 & Shubenacadie & \\
\hline 20 July, 1752 & 300 & Minas Basin & \\
\hline 15 Oct., 1765 & 20,000 & Pictou Harbour & \\
\hline 7 Мау, 1765 & $\quad 510$ & Crow Harbour & \\
\hline 5 Aug., 1758 & 860 & Mahone Bay & \\
\hline 22 Oct., 1765 & 4,000 & Chedebucto & \\
\hline 15 Oct., 1765 & 20,000 & Merigomish & \\
\hline 27 Oct., 1766 & $\quad 5,000$ & Taylor's Harbour & \\
\hline 17 Sept., 1763 & . & Windsor Rd. & \\
\hline 17 Sept., 1763 & 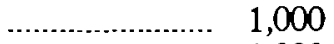 & Windsor Rd. & \\
\hline 22 Nov., 1764 & 1,000 & Shubenacadie & \\
\hline 17 Sept., 1763 & (.)..................... & Windsor $\mathrm{Rd}$. & \\
\hline 15 May, 1765 & ................... & Shubenacadie & \\
\hline 22 Nov., 1764 & 1,000 & Shubenacadie & \\
\hline 17 Sept., 1763 & . & Windsor Rd. & \\
\hline 15 Oct., 1763 & . 1,000 & Windsor Rd. & \\
\hline 3 Sept., 1765 & 10,000 & Halifax Co. & \\
\hline 3 Sept., 1766 & 10,000 & Ship Harbour & \\
\hline 15 Oct., 1763 & 1,000 & F. Sackville Rd. & \\
\hline 30 May, 1765 & .. 18,600 & Minas Basin & \\
\hline 18 Oct., 1765 & 100,140 & Burton & \\
\hline 31 Oct., 1765 & 125,000 & Sunbury & \\
\hline 19 Oct., 1765 & 20,000 & Maugerville & \\
\hline 19 Oct., 1765 & 20,000 & Newton & \\
\hline 21 July, 1761 & 500 & Newport & \\
\hline 15 Dec., 1765 & 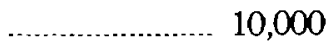 & St. John R. & \\
\hline 15 Dec., 1774 & 30,000 & St. John R. & \\
\hline 15 April, 1774 & 920 & St. John R. & \\
\hline 10 June, 1754 & $\ldots \ldots \ldots 0 . \quad 1,000$ & Lawrencetown & \\
\hline
\end{tabular}


Record of Land escheated in Nova Scotia, 1770-1788.-Continued.

\begin{tabular}{|c|c|c|c|}
\hline \multicolumn{4}{|c|}{1784} \\
\hline 10 June, 1754 & 1,000 & Lawrencetown & \\
\hline 30 July, 1774 & ...... 20,000 & Sheet Harbour & \\
\hline 27 Sept., 1773 & 10,000 & Head of B. of Fundy & \\
\hline 29 July, 1763 & $\begin{array}{ll}1,500\end{array}$ & New Dublin & \\
\hline 7 May, 1763 & ........................ & & \\
\hline \multicolumn{4}{|c|}{1785} \\
\hline 20 Sept., 1759 & …................. & St. Margaret's B. & \\
\hline 11 June, 1773 & 400 & Cow Bay & \\
\hline 30 April, 1765 & 10,000 & Chebucto & \\
\hline 29 July, 1766 & 100,000 & Jedore Harbour & \\
\hline 15 June, 1765 & 3,000 & Colchester & \\
\hline 6 Sept., 1759 & 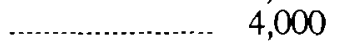 & Annapolis R. & \\
\hline 30 Apr., 1760 & (n) & St. Margaret's B. & \\
\hline 1752 & 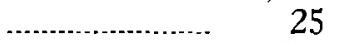 & Halifax Pennisula & \\
\hline 12 Sept., 1763 & 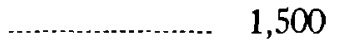 & New Dublin & \\
\hline 27 Aug., 1764 & 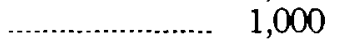 & Windsor Rd. & \\
\hline 11 Feb., 1767 & 1,000 & St. Margaret's B. & \\
\hline 7 April, 1767 & 1,989 & Yarmouth Town & 125,414 \\
\hline \multicolumn{4}{|c|}{1786} \\
\hline 15 Oct., 1765 & 20,000 & Merigomish & \\
\hline 10 June, 1754 & .................. 1,000 & Lawrence town & \\
\hline 1752 & 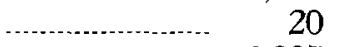 & Halifax Peninsula & \\
\hline 30 Sept., 1767 & 2,997 & Yarmouth Town. & \\
\hline 16 Mar., 1765 & (......................... & Wilmot & \\
\hline 15 May, 1765 & 2,000 & Shubenacadie & \\
\hline & -........................ & Halifax Peninsula & \\
\hline 23 July, 1765 & .......................... & Pisiquid Rd. & \\
\hline 11 Oct., 1762 & (n)....................... & Cumberland & \\
\hline 20 July, 1767 & 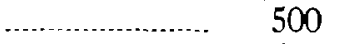 & Pisiquid Rd. & \\
\hline 29 Aug., 1759 & 1,500 & Pisiquid R. ....... & 29,822 \\
\hline \multicolumn{4}{|c|}{1788} \\
\hline 22 Nov., 1763 & (n................... & Cumberland & \\
\hline 20 Aug., 1764 & 500 & Cumberland & \\
\hline 31 Oct., 1764 & . & Amherst & \\
\hline 11 Jan., 1768 & . & Cumberland & \\
\hline 30 Oct., 1765 & 20,000 & Green's River & \\
\hline 23 Aug., 1764 & 1,000 & 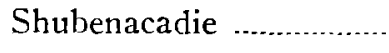 & 24,000 \\
\hline \multirow{2}{*}{\multicolumn{3}{|c|}{ 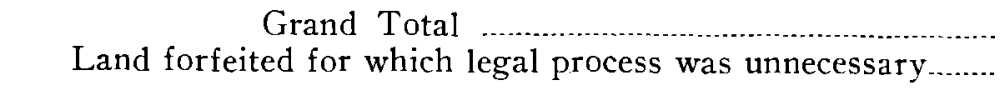 }} & $2,065,667$ \\
\hline & & & 509,000 \\
\hline \multicolumn{3}{|c|}{ Total land forfeited $1770-1788$} & $2,574,667$ \\
\hline Computed & from Case Book of & & $\begin{array}{l}. \text { S., and } \\
\text { lgh the }\end{array}$ \\
\hline
\end{tabular}

